\title{
Minority Women Deputies in the Soviet Parliament, 1989-1991: Intersectionality in the Imperial Situation
}

\author{
Ivan Sablin \\ Heidelberg University
}

\begin{abstract}
This article discussed the participation of minority women deputies in the parliamentary debates of the Perestroika, namely in the Congress of People's Deputies (CPD), which was formally the supreme government body of the Soviet Union in 1989-1991. The speeches and statements of minority women deputies highlighted their perspectives on the multifaceted crisis of the Soviet Union. Some of the women represented especially marginalized groups, like the indigenous peoples of the Far East and mountain herders of Kirghizia, and for the first time gained the opportunity to express their grievances in a public debate. The article focused on the grievances, which minority women deputies articulated, and the solutions, which they proposed for mitigating or overcoming them. The study was informed by the concepts of intersectionality and the imperial situation. Although nationality (ethnicity) was an important self-categorization for many of those minority women who spoke at the five congresses, the meanings, ascribed to ethnonational categories, and the policy proposals, deriving from them, were very different. Even when grievances were "nationalized," the proposed solutions could also be anti-nationalist. Besides, the same grievances could be refracted not only through nationality but also through gender, regional, local, occupational, and other categories. Some of the issues, like those related to occupation and environment, were part of the broader public discussions. Even though their grievances had often been formulated in terms of nationality and also originated in the centralized mismanagement, most of the minority women deputies viewed the Soviet Union as the main source of possible solutions.
\end{abstract}




\section{Introduction $^{1}$}

The Congress of People's Deputies (CPD), which was formally the supreme government body of the Union of Soviet Socialist Republics (USSR) in 1989-1991, was created as part of the broad reforms of the Perestroika (1987-1991). The economic reforms, initiated by Mikhail Sergeevich Gorbachev already in 1985, gave way to a complete overhaul of the political and economic systems since 1987, and culminated in the collapse of state socialism and the dissolution of the Soviet Union in 1991. The CPD and the standing parliamentary body, the reformed bicameral USSR Supreme Soviet, now elected by the CPD, reflected the broader transformations. Some contemporary commentators perceived the $\mathrm{CPD}$ as the source of a "rudimentary, but quite real, degree of public accountability," which had been most evident in economic affairs and the "savage criticism" of the state of the economy and the inability of government to remedy the situation on the parliamentary floor. ${ }^{2}$ Others stressed that by contrast with the previous rubberstamp legislature, the pre-reform Supreme Soviet, the CPD was "an event of historic importance," as it marked the advance of democratization, even though only 1,500 out of its 2,250 deputies were elected directly, and 399 among those elected still had no rival candidates. The special representation of the ethnonational units through the 750 "national-territorial" deputies, in addition to the general representation of the country through the 750 "territorial" deputies, made the nonRussian deputies quite prominent. At the CPD, many of them pointed to the ethnonational tensions and differences within the USSR. ${ }^{3}$

In this respect, the experience of the CPD contributed to the ongoing debate on the Perestroika and the collapse of the USSR at large. Some saw the collapse of the state socialist system as predetermined by its economic features, ${ }^{4}$ while others underscored the failure of the Soviet leadership, indoctrinated by the Communist ideology, to reform what was essentially irreformable. ${ }^{5}$ There were also those who stressed that the development of nationalism within the USSR's institutions contributed to the swift disintegration of the Soviet federation. ${ }^{6}$ Others pointed

\footnotetext{
${ }^{1}$ The research for this article was done as part of the project 'ENTPAR: Entangled Parliamentarisms: Constitutional Practices in Russia, Ukraine, China and Mongolia, 1905-2005', which received funding from the European Research Council (ERC) under the European Union's Horizon 2020 research and innovation program (grant agreement No 755504).

${ }^{2}$ Ed A. Hewett, "Perestroyka and the Congress of People's Deputies," Soviet Economy 5, no. 1 (1989): 47-49.

${ }^{3}$ Oleg Glebov and John Crowfoot, eds., The Soviet Empire: Its Nations Speak out: The First Congress of People's Deputies, Moscow, 25 May to 10 June 1989 (with an Introduction by Ernest Gellner) (Chur: Harwood Academic Publishers, 1989), xxviii.

${ }^{4}$ Yegor Gaidar, Collapse of an Empire: Lessons for Modern Russia. (Washington, DC: Brookings Institution Press, 2010).

${ }^{5}$ Stephen Kotkin, Armageddon Averted: The Soviet Collapse, 1970-2000, Updated edition (Oxford: Oxford University Press, 2008), 2-3, 5.

${ }^{6}$ Ronald Grigor Suny, The Revenge of the Past: Nationalism, Revolution, and the Collapse of the Soviet Union (Stanford, CA: Stanford University Press, 1993).
} 
to the multitude of problems, which the reforms had to address, and the dynamics of the transformation. As noted by Archie Brown, the large-scale change in the Soviet system was by no means predetermined, and there was no overt pressure on the party leadership from below, while the possible reforms of the economy did not predestine democratization. It was the reforms which destroyed the foundations of the Soviet regime, and not the crisis of the regime which produced the reforms. According to Brown, the Perestroika ("reconstruction") was a momentous effort by a small minority in the Communist Party of the Soviet Union (CPSU) leadership (Gorbachev in the first place) initially to reform the Soviet system and, then, to transform it. It required, however, the simultaneous transformation of the state socialist economy, of the highly authoritarian political system, and of the nominally federal yet in practice unitary system which conflicted with the multinational composition of the USSR. What made the situation even more complex was that by contrast to the Eastern European socialist states, the Soviet regime was not backed by a foreign power. $^{7}$

Although only two thirds of the 2,250 CPD deputies were elected, with the rest having been nominated by different organizations, while no organized parties other than the CPSU had access to the elections, the CPD can be considered the country's first parliament. Despite the issues with representation, deliberation (due to the short sessions), its sovereignty within the system (due the continued presence of the CPSU), and the responsibility of the cabinet to it, the CPD proved to be a deliberative institution of dissensus ${ }^{8}$ and a major forum where Soviet citizens had the opportunity to express their concerns freely and to the largest imaginable audience, thanks to the live broadcast of the First CPD, which reached some 90 to 100 million people, and extensive coverage of the other four. Furthermore, the convocation of the CPD was met with relatively high hopes among the population. ${ }^{9}$

The CPD and the reformed Supreme Soviet were also the first regular parliamentary institutions in which Soviet women could participate, given that the universally elected bodies of the 1917 Revolution had been disbanded by the Bolsheviks and their allies, while the Soviet congresses and "parliaments," the Supreme Soviets convened since 1938, had only nominal authority. The CPD and the USSR Supreme Soviet consisted predominantly of men. Yet some of the 352 women at the CPD also had a chance to voice their concerns and participate in deliberating the country's future. Special representation for women via nomination from organizations,

\footnotetext{
${ }^{7}$ Archie Brown, Seven Years That Changed the World: Perestroika in Perspective (Oxford: Oxford University Press, 2007), 4-7, 10-20.

${ }^{8}$ Pasi Ihalainen, Cornelia Ilie, and Kari Palonen, "Parliament as a Conceptual Nexus," in Parliaments and Parliamentarism: A Comparative History of a European Concept, ed. Pasi Ihalainen, Cornelia Ilie, and Kari Palonen (New York: Berghahn Books, 2016), 1-16.

${ }^{9}$ Brown, Seven Years That Changed the World: Perestroika in Perspective, 120.
} 
including the Committee of Soviet Women (CSW), boosted their numbers, since few women were elected directly. Around one third of the women deputies belonged to non-Russian minorities (Russians made up 50,8 percent of the USSR population in 1989), ${ }^{10}$ albeit few of them explicitly identified as non-Russian. The CPD was hence a highly asymmetric body in gender terms, since it consisted predominantly of men. Furthermore, the special instruments, which were supposed to give voice to underrepresented groups, still favored either non-Russian men or Russian women, leaving many non-Russian women outside the space of official politics.

This study sought to shed some light on the position of the women deputies with minority backgrounds in the parliamentary debates of the Perestroika. The main research questions were what grievances - types of resource or political deprivation, which lead to collective behavior ${ }^{11}-$ the minority women deputies articulated and what possible solutions they proposed to mitigate or overcome these grievances. Attempting to make the overview of different positions as broad as possible, this study addressed the positions of those women deputies who either resided in or represented the ethno-national units of the multilayered Soviet state - the "union" soviet socialist republics (SSRs), with the exception of the Russian republic, as well as the autonomous soviet socialist republics (ASSRs), autonomous regions (ARs), and autonomous districts within the union republics. The sources consisted of the complete published verbatim reports of the five CPDs. ${ }^{12}$

\footnotetext{
10 "Vsesoiuznaia Perepis' Naseleniia 1989 Goda: Natsional'nyi Sostav Naseleniia Po Respublikam SSSR," accessed September 29, 2019, http://www.demoscope.ru/weekly/ssp/sng_nac_89.php.

${ }^{11}$ Patrick M. Regan and Daniel Norton, "Greed, Grievance, and Mobilization in Civil Wars," Journal of Conflict Resolution 49, no. 3 (2005): 319.

${ }^{12}$ Pervyi S"ezd narodnykh deputatov SSSR, Stenograficheskii Otchet, 25 Maia-9 Iiunia 1989 g., vol. 1 (Moscow: Izdanie verkhovnogo soveta SSSR, 1989); Pervyi S"ezd narodnykh deputatov SSSR, Stenograficheskii Otchet, 25 Maia-9 Iiunia 1989 g., vol. 2 (Moscow: Izdanie verkhovnogo soveta SSSR, 1989); Pervyi S"ezd narodnykh deputatov SSSR, Stenograficheskii Otchet, 25 Maia-9 Iiunia 1989 g., vol. 3 (Moscow: Izdanie verkhovnogo soveta SSSR, 1989); Vtoroi S"ezd Narodnykh Deputatov SSSR, 12-24 Dekabria 1989 g.: Stenograficheskii Otchet, vol. 1 (Moscow: Izdanie verkhovnogo soveta SSSR, 1989); Vtoroi S"ezd narodnykh deputatov SSSR, Stenograficheskii Otchet, 12-24 Dekabria 1989 g., vol. 2 (Moscow: Izdanie verkhovnogo soveta SSSR, 1989); Vtoroi S"ezd narodnykh deputatov SSSR, Stenograficheskii Otchet, 12-24 Dekabria 1989 g., vol. 3 (Moscow: Izdanie verkhovnogo soveta SSSR, 1989); Pervyi S"ezd narodnykh deputatov SSSR, Stenograficheskii Otchet, 25 Maia-9 Iiunia 1989 g., vol. 4 (Moscow: Izdanie verkhovnogo soveta SSSR, 1989); Vneocherednoi Tretii S"ezd Narodnykh Deputatov SSSR, 12-15 Marta 1990 g.: Stenograficheskii Otchet, vol. 1 (Moscow: Izdanie verkhovnogo soveta SSSR, 1990); Vneocherednoi Tretii S"ezd narodnykh deputatov SSSR, Stenograficheskii Otchet, 12-15 Marta 1990 g., vol. 2 (Moscow: Izdanie verkhovnogo soveta SSSR, 1990); Vneocherednoi Tretii S"ezd Narodnykh Deputatov SSSR, 12-15 Marta 1990 g.: Stenograficheskii Otchet, vol. 3 (Moscow: Izdanie verkhovnogo soveta SSSR, 1990); Chetvertyi S"ezd Narodnykh Deputatov SSSR, 17-27 Dekabria 1990 g.: Stenograficheskii Otchet, vol. 1 (Moscow: Izdanie verkhovnogo soveta SSSR, 1991); Chetvertyi S"ezd narodnykh deputatov SSSR, Stenograficheskii Otchet, 17-27 Dekabria 1990 g., vol. 2 (Moscow: Izdanie verkhovnogo soveta SSSR, 1991); Chetvertyi S"ezd Narodnykh Deputatov SSSR, 17-27 Dekabria 1990 g.: Stenograficheskii Otchet, vol. 3 (Moscow: Izdanie verkhovnogo soveta SSSR, 1991); Vneocherednoi Piatyi S"ezd Narodnykh Deputatov SSSR: Biulleten’ No. 1, 2 Sentiabria 1991 g. (Moscow: Otdel opublikovaniia aktov Verkhovnogo Soveta SSSR, 1991); Vneocherednoi Piatyi S"ezd Narodnykh Deputatov SSSR: Biulleten' No. 2, 2 Sentiabria 1991 g. (Moscow: Otdel opublikovaniia aktov Verkhovnogo Soveta SSSR, 1991); Vneocherednoi Piatyi S"ezd Narodnykh Deputatov SSSR: Biulleten' No. 3, 3 Sentiabria 1991 g. (Moscow: Otdel opublikovaniia aktov Verkhovnogo Soveta SSSR, 1991); Vneocherednoi Piatyi S"ezd Narodnykh Deputatov SSSR: Biulleten' No. 4, 3 Sentiabria 1991 g. (Moscow: Otdel opublikovaniia aktov Verkhovnogo Soveta SSSR, 1991); Vneocherednoi Piatyi S"ezd Narodnykh Deputatov SSSR: Biulleten' No. 5, 4 Sentiabria 1991 g.
} 
Many of the minority women deputies at the CPD had positions in the CPSU, but party membership was not a key factor. The 1,957 Communist deputies at the congress split up into different factions, with neither the conservative pro-Soviet "Union" Group nor the liberal InterRegional Group having a majority. In occupational terms, most of the active minority women deputies were scholars, industrial and agricultural workers, doctors, and journalists. Under state socialism women entered waged labor and hence became rightful part of workers and peasants (and later the Soviet "people" or nation) to be represented at the soviet congresses and in the Supreme Soviet. ${ }^{13}$ Because the pre-1989 Supreme Soviet was a nominal parliament, which was steered by the CPSU Central Committee, it is questionable how much the representation of women mattered. Although the political reform doubled the number of women in the CPSU Central Committee, in 1990 they only accounted for 8 percent or 33 of its 412 members. ${ }^{14}$

The study was informed by two main concepts: intersectionality and the imperial situation. Intersectionality foregrounds the complex relationships between different social categories, such as gender, race, ethnicity, class, religion, and others, and the overlapping power asymmetries which could stem from these categories. ${ }^{15}$ In the Soviet context, this meant that many non-Russian women experienced double power asymmetries, as women and as non-Russians. Women also faced additional hardships depending on occupation and in rural settings. ${ }^{16}$ Some women's issues had been discussed before the Perestroika, but others, like prostitution, high infant mortality rates, or abortion, were largely taboo between the 1920s and the late 1980s. As Mary Buckley pointed out, the "women's question" emerged in public debates parallel to the "nationality question," but was met with much bigger hesitation on behalf of the elites. ${ }^{17}$ This can also be seen in the debates at the CPD which put the "nationality question" to the forefront. ${ }^{18}$ Furthermore, women of all backgrounds became even more excluded from politics during the post-Soviet period in most of the former USSR. ${ }^{19}$

(Moscow: Otdel opublikovaniia aktov Verkhovnogo Soveta SSSR, 1991); Vneocherednoi Piatyi S"ezd narodnykh deputatov SSSR, Biulleten' No. 6, 5 Sentiabria 1991 g. (Moscow: Otdel opublikovaniia aktov Verkhovnogo Soveta SSSR, 1991).

${ }^{13}$ Wendy Z. Goldman, Women at the Gates: Gender and Industry in Stalin's Russia (Cambridge: Cambridge University Press, 2002), 20.

${ }^{14}$ Peter Lentini, "A Note on Women in the CPSU Central Committee," Europe-Asia Studies 45, no. 4 (1990): 790.

${ }^{15}$ Gill Valentine, "Theorizing and Researching Intersectionality: A Challenge for Feminist Geography," The Professional Geographer 59, no. 1 (2007): 10-21.

${ }^{16}$ Liubov Denisova, Rural Women in the Soviet Union and Post-Soviet Russia, ed. Irina Mukhina (London: Routledge, 2010).

${ }^{17}$ Mary Buckley, "Glasnost and the Woman Question," in Women and Society in Russia and the Soviet Union, ed. Linda Edmondson (Cambridge: Cambridge University Press, 1992), 202-3.

${ }^{18}$ Carolina de Stefano, "An Old Soviet Response and a Revolutionary Context: Dealing with the National Question in the Committees of the USSR Congress of People's Deputies (1989-1991)," Journal of Eurasian Studies 11, no. 1 (2020): 53-61.

${ }^{19}$ Carol Nechemias, "Politics in Post-Soviet Russia: Where Are the Women?," Demokratizatsiya 8, no. 2 (2000): 199-199. 
At the same time, in the imperial situation, which can be defined as the "unstable balance in a composite society" with "conditional, fluid, and situational" social boundaries, social categories are not holistic entities. ${ }^{20}$ Although the differentiation into categories ${ }^{21}$ was helpful analytically, it was precisely the dynamics and the overlaps of self-categorizations which were at the center of this study. The parliament in this regard can be seen as the imperial situation in miniature, a public space where diversity is performed and where options for defining and articulating grievances become available and enabled. The debates at the CPD demonstrated that women deputies did not necessarily see themselves in a situation of national or multilayered oppression and singled out only those grievances which they perceived as the most pressing ones or which they considered mendable through the CPD. This article's approach is hence similar to that of Elise Giuliano who proposed to take a step back from essentializing nationality and discuss concrete grievances not as being present or absent but as being developed through interaction. ${ }^{22}$

A brief overview of all delivered speeches and opinion statements in the discussions at the five CPDs confirmed that nationality (ethnicity) was an important self-categorization for many of those minority women who spoke. This reflected the important role of nationalism in the collapse of the Soviet Union. ${ }^{23}$ At the same time, a more careful analysis demonstrated that both the meanings, ascribed to ethnonational categories, and the policy proposal deriving from them were very different. On the one hand, this made the CPD similar to the State Duma of the Russian Empire, as it also offered a shared language of expressing particularistic grievances through ethnicity and thereby fostering nationalism. ${ }^{24}$ Last but not least, the parliamentary setting demonstrated that even when grievances were "nationalized," the proposed solutions could also be anti-nationalist. Besides, the same grievances could be refracted not only through nationality but also through gender, regional, local, occupational, and other categories.

\footnotetext{
${ }^{20}$ Ilya Gerasimov et al., "New Imperial History and the Challenges of Empire," in Empire Speaks out: Languages of Rationalization and Self-Description in the Russian Empire, ed. Ilya Gerasimov, Jan Kusber, and Alexander Semyonov (Leiden: Brill, 2009), 3-32; Ilya Gerasimov et al., "The Centrality of Periphery," Ab Imperio, no. 1 (2012): 19-20.

${ }^{21}$ Vivian L. Vignoles, Seth J. Schwartz, and Koen Luyckx, "Introduction: Toward an Integrative View of Identity," in Handbook of Identity Theory and Research, ed. Seth J. Schwartz, Koen Luyckx, and Vivian L. Vignoles (New York: Springer, 2011), 1-27.

${ }^{22}$ Elise Giuliano, Constructing Grievance: Ethnic Nationalism in Russia's Republics (Ithaca, NY: Cornell University Press, 2011), 1-13.

${ }^{23}$ Suny, The Revenge of the Past: Nationalism, Revolution, and the Collapse of the Soviet Union.

${ }^{24}$ Alexander Semyonov, "The Real and Live Ethnographic Map of Russia': The Russian Empire in the Mirror of the State Duma," in Empire Speaks out: Languages of Rationalization and Self-Description in the Russian Empire, ed. Ilya Gerasimov, Jan Kusber, and Alexander Semyonov (Leiden: Brill, 2009), 191-228.
} 


\section{National Grievances}

Women deputies were marginalized at the CPDs in terms of both their share and, arguably, their access to the parliamentary floor. Some of them nevertheless were members of national elites and the main speakers for the new sovereign republics. Others viewed themselves as the representatives of their ethnic groups and spoke on their behalf. The solutions to the nationallydefined grievances ranged from full sovereignty of the ethnonational republics to keeping the Soviet Union in a relatively unchanged state.

The sovereignty of the union republics was included in the 1977 USSR Constitution, but it was during the First CPD (May 25-June 9,1989) when the discussion of making their sovereignty genuine became union-wide. The Baltic deputies were especially prominent in formulating national grievances and proposing a radical reform of the Soviet federation. The First CPD was predated by the declaration of sovereignty by the Estonian SSR on November 16, 1988, and was accompanied by that of the Lithuanian SSR on May 26, 1989. Baltic women deputies played a major role in the discussions. The economist Kazimira Danute Prunskienė, elected in Lithuania, brought the joint program of the Baltic republics to the parliamentary floor. As one of the founding members of the Lithuanian reform movement Sajūdis, which led the struggle for political independence of Lithuania, ${ }^{25}$ Prunskienè was one of the recognized national leaders in the CPD. Arguing that economic reforms could not be implemented under the over-centralized governance of the Soviet economy, Prunskiene maintained that decentralization was the way forward. She decried the accumulation of profits in the center and low purchasing prices for agricultural produce. Prunskiene argued that the economic independence of the republics, including their right to control own monetary and financial systems and foreign trade, was a prerequisite for the reforms in both the republics and the whole union, while the horizontal connections between the republics and their industries had to replace the top-down topology of the USSR. She also admitted that both the Perestroika and the "readiness" for self-government were uneven across the USSR but did not see that as a problem. ${ }^{26}$ The Baltic plan envisioned the transformation of the union into the "commonwealth of sovereign republics" with an inter-republican apparatus. ${ }^{27}$

In the political sphere the Soviet takeover of the Baltic republics in the aftermath of the Molotov-Ribbentrop Pact (August 23, 1939) and other Soviet-German agreements of 1939,

\footnotetext{
25 "Kazimira Danute Prunskienė," Government of the Republic of Lithuania [Web Archive Copy], October 14, 2006, https://web.archive.org/web/20061014172146/http://www.lrv.lt/main_en.php?cat=16\&gr=3\&sub=9\&d=2001.

${ }^{26}$ The citations for the specific volumes include the CPD and the volume numbers. CPD I, 3: 58-61.

${ }^{27}$ CPD I, 3: 62.
} 
establishing the respective zones of influence, was a key issue in the Soviet parliament, and the Second CPD (December 12-24, 1989) explicitly condemned one of the treaties. ${ }^{28}$

The discussions of national grievances under the Soviet regime, however, went beyond the Baltic republics. Klara Semenovna Khallik, a social scientist, specializing in ethnic relations, elected in Estonia, argued that the core of the national problems lay in the bureaucratic socialism and the methods of imperial rule and that all issues in the USSR were national. She asserted that unity could not be kept with the old methods and that only the reinstitution of the right to national self-determination was a way forward. In practical terms, this meant the establishment of a union of "equal sovereign states" and self-government for those peoples who did not have statehood (within the Soviet system). Khallik also suggested that a treaty had to become the source of the federal law. She also specified that the national problems also concerned Russia, which had to be governed as a country and not as a conglomerate of regions. Khallik urged against substituting Russian national consciousness with an all-Soviet identity and proposed to create state authorities for Russia which would make those of the USSR obsolete. Finally, Khallik pointed to the international experience of integration of free peoples, probably implying the European Community. ${ }^{29}$ Khallik's position on nationalism had changed during the Perestroika, since in 1988 she had denounced it as a threat to the reforms. ${ }^{30}$

The debates at the Second CPD revolved around Article 6 of the Constitution (on the leadership of the CPSU) and the USSR Constitutional Oversight Committee, which could hamper the political reforms in the republics. Marju Lauristin, a sociologist, elected in Estonia, suggested to make the abolition of Article 6 part of the congress's agenda, but this motion was voted down. She also suggested to postpone the establishment of the USSR Constitutional Oversight Committee to the next congress, but it was nevertheless created at the Second CPD. ${ }^{31}$ Just like in the case of Prunskiene, Lauristin had a recognized position of leadership in the Baltic national movements. She was a dissident and a co-founded of the Popular Front of Estonia, the main movement opposing the Soviet rule.

Leonida Lari (Liubov' Ivanovna Iorga), a poet, elected in Moldova, connected the two issues, stressing that as a deputy she could not simultaneously follow the will of the people and the Constitution with Article 6 in it. ${ }^{32}$ She then defended the constitutions of the Baltic republics against the criticism of the Presidium of the USSR Supreme Soviet.

\footnotetext{
${ }^{28}$ CPD II, 4: 612-4.

${ }^{29}$ CPD I, 2: 411-13.

${ }^{30}$ Steve Goldstein, "Nationalism Divides Estonia, and a Family," The Philadelphia Inquirer, February 15, 1988, A04.

${ }^{31}$ CPD II, 1: 23, 40; CPD II, 4: 5-6.

${ }^{32}$ CPD II, 3: 263.
} 
I do not understand: if the constitutions of the republics and the Constitution of the USSR should be the same in everything, why do we need so many constitutions? Why should we hide behind the papers? Then we must publicly admit that we have a metropolitan constitution and only an illusion of the republics' sovereignty. The Constitution of the USSR should be based on the constitutions of the republics, and it would be best of all if the republics would coexist within the USSR on the basis of agreements, as it is customary in all non-colonial, civilized countries. ${ }^{33}$

Leonida Lari, who was one of the leaders of the Moldovan Movement for National Revival, ${ }^{34}$ also used both issues to express her position on Moldova's similarity to the Baltic republics, as Bessarabia was also annexed in the aftermath of the Molotov-Ribbentrop Pact. ${ }^{35}$

The slogans of republican sovereignty (including that of Russia) became the main drivers of the political transformations in the Soviet Union. Most of those minority women deputies who articulated national grievances, however, saw the solution to the problems in the Soviet Union rather than republics. The deputies from Central Asia were especially prominent in the discussions. Bikhodzhal Fatkhitdinovna Rakhimova, a Communist functionary from Tajikistan, nominated by the CSW, also criticized the low purchasing prices for agricultural produce and the asymmetries in the Soviet economy which made Tajikistan a resource-oriented (mining and cotton-producing) republic. She called for processing cotton in the republic but did not suggest its economic or political sovereignty. ${ }^{36}$ Roza Atamuradovna Bazarova, the Chairwoman of the Presidium of Turkmenistan Supreme Soviet, elected in the republic, also stressed the resource orientation of her republic, noting that the state bought oil and cotton but did not provide goods. She argued that the unemployment in the republic contradicted the Perestroika's intensive industry approach, which would ultimately decrease the number of jobs. As a solution, Bazarova suggested more state control in supplying the republic with goods, leaving only 10 percent to the market, and in ensuring centralized employment policy. ${ }^{37}$

The economic situation of Central Asia, confined to raw material production and dependent on the center, fit well into the metaphor of a domestic "Third World." 38 The divergence of opinions between the Baltic and Central Asian deputies led to direct confrontations at the Second CPD.

\footnotetext{
${ }^{33}$ CPD II, 1: 94.

34 “Ushla iz zhizni poetessa Leonida Lari," Publika, December 11, 2011, https://ru.publika.md/ushla-iz-zhiznipoyetessa-leonida-lari_360631.html.

${ }^{35}$ CPD II, 4: 276-7.

${ }^{36}$ CPD II, 2: 35.

${ }^{37}$ CPD II, 2: 49-51.

${ }^{38}$ Madelein Reeves, Border Work: Spatial Lives of the State in Rural Central Asia (Ithaca, NY: Cornell University Press, 2014).
} 
Bazarova opposed the Baltic republics in the discussion of the USSR Constitutional Oversight Committee, asserting that separate legislation in the republics would lead to anarchy and collapse. ${ }^{39}$ Mikhail Lazarevich Bronshtein, an economist, elected in Estonia, claimed that it was not possible for the Soviet economy to compensate for the high fertility rates in Uzbekistan. To this Rano Akhatovna Ubaidullaeva, an economist from Uzbekistan, nominated by the CSW, contended that the situation when a resource-rich republic was on the threshold of poverty should not be blamed on the Uzbek people, since it emerged due to the command economy in the Era of Stagnation. ${ }^{40}$

The critical economic and environmental situation of the indigenous peoples of the Far East, who did not have any autonomy, motivated Evdokiia Aleksandrovna Gaer, a Nanai scholar, elected in the Far East, to speak of their very survival. She decried the loss of indigenous languages and cultures, the ousting of the indigenous peoples from different labor niches, and the high sickness rates and the low life expectancy among them. Together with the non-indigenous rural population, they also endured underfinancing of the infrastructure, like schools. Gaer suggested reviving the special status of local indigenous territories with "elements of national sovereignty," creating an autonomous region in the Amur basin, and an association of the peoples of the north with the support of the government. ${ }^{41}$

Other discussions touched upon the cases interethnic violence across the USSR. Responding to the Nagorno-Karabakh (an Armenian-majority AR in Azerbaijan) conflict, Piusta Azizbekova, a museum director, elected in Azerbaijan, called nationalism its main reason. Citing the large number of refugees, she cautioned against similar situations of non-titular nations in other Soviet units and urged for a legal state solution. A vocal supporter of internationalism, Azizbekova called for common principles in governing economy and for union-wide laws. She protested against the group interests which threatened the foundations of the Soviet multinational state, maintaining that this would destroy the ties between the republics and deform the existing economic relations. Furthermore, Azizbekova cautioned against spiritual "autonomization" and national self-isolation which threatened the "unique" Soviet culture. ${ }^{42}$

At the First CPD, Galina Vasil'evna Starovoitova, a Russian ethnographer, elected in Armenia, also called for a legal solution, but suggested to give Nagorno-Karabakh a voice through representation in the USSR Supreme Soviet. ${ }^{43}$ In a similar manner, Diana Varlamovna Khugaeva,

\footnotetext{
${ }^{39}$ CPD II, 4: 19.

${ }^{40}$ CPD II, 2: 275, 323-4.

${ }^{41}$ CPD I, 3: 85-9.

${ }^{42}$ CPD I, 2: 227-30.

${ }^{43}$ CPD I, 1: 258.
} 
an agricultural worker, elected in South Ossetia called for legal solutions of the conflict in the South Ossetian AR (in Georgia) and suggested extending the rights of autonomous units, giving them inter alia representation in the USSR Constitutional Oversight Committee. ${ }^{44}$ Starovoitova's position was, however, different from that of the USSR's supporters. At the Third CPD (March 12-15, 1990) she defended Lithuania against the CPD's denouncement of its independent policies. Comparing the Baltic case to Nagorno-Karabakh, she claimed that ignoring the latter's demands to move to a different union republic ultimately led to the crisis. ${ }^{45}$

El'mira Mikail kyzy Kafarova, who headed the Azerbaijani Supreme Soviet in 1989-1991 and was elected in the republic, admitted at the Fourth CPD (December 17-27, 1990) that she had hoped that Gorbachev, who was elected President at the Third CPD, would deal with the problem, but he delegated it to the USSR Supreme Soviet. Seeing no point in that, Kafarova argued that the problem had to be resolved by the people of Azerbaijan and made Azerbaijan's participation in the future union treaty conditioned by the guarantee of the republics' territorial integrity. Kafarova was overall critical of the union at the Fourth CPD, claiming that in its current form it hampered the Perestroika, and supported a "commonwealth of sovereign states" based on inter-republican connections. ${ }^{46}$

Both the divisions among the republics of the USSR and the growing popularity of independence among the elites in some of them reflected in the referendum on the future of the Soviet Union on March 17, 1991. Most of the voters supported preserving the USSR as a renewed federation of equal sovereign republics, but the vote did not take place in Armenia, Estonia, Georgia, Latvia, Lithuania, and Moldova. ${ }^{47}$ The discontent with Gorbachev and the Soviet government did not necessarily lead to a pro-independence stance. Sazhi Zaindinovna Umalatova, an industrial worker in the Chechen-Ingush ASSR, nominated by the CPSU, for instance, was critical of the situation in the republic at the Second CPD, criticizing the economic asymmetries (resource orientation and poverty), denouncing its temporary abrogation under Stalinism, and calling for more economic autonomy. ${ }^{48}$ At the Fourth CPD, however, Umalatova proposed a vote of no confidence against Gorbachev, accusing him of destroying the country, inciting people against each other, and making a great power go begging for money. ${ }^{49}$ Her motion was not supported. The conservative opposition, which included members of the "Union" Group, attempted a coup d'état against Gorbachev on August 19-22, 1991, contributing to the ultimate

\footnotetext{
${ }^{44}$ CPD II, 3: 451-3.

${ }^{45}$ CPD III, 3: 134-5.

${ }^{46}$ CPD IV, $1: 458-1$.

47 The regions opposing the republican authorities of Georgia and Moldova participated in the referendum.

${ }^{48}$ CPD II, 1: 264-7.

${ }^{49}$ CPD IV, 1: 12.
} 
dissolution of the USSR on December 26, 1991. Umalatova was one of the leaders of a group of deputies who attempted to convene the Sixth CPD on March 17, 1992, on the referendum's anniversaryбы but did not have a quorum. ${ }^{50}$

\section{Other Grievances}

In many cases national grievances were seen as the core of other problems, but it was possible to single out those which focused on non-national categories, such as gender, region, locality, and occupation. The issues related to labor, which was often discussed in gendered terms, and the environment proved to be especially pressing. Although these issues were also often "nationalized," the solutions predominantly revolved around the increased funding and control by the Soviet state.

Already at the First CPD, Azizbekova noted that women rarely got the floor. ${ }^{51}$ During the Fourth CPD, Umalatova had to defend her subjectivity as a deputy when being asked about the source for her anti-Gorbachev motion. ${ }^{52}$ The issues of representation and women in politics and other spheres were explored in detail in the two speeches by the Russian Communist functionary Valentina Ivanovna Matvienko, ${ }^{53}$ nominated from the CSW, at the Second CPD. Matvienko noted that women were barely represented in the highest level of government and denounced discrimination and gender stereotypes. Matvienko asserted that it was women who had to carry the burden of the Perestroika due to the difficult economic situation and that women were employed in the national economy as men but also took care of households and bring up children. It is noteworthy that her larger second speech itself was met with a lack of attention from the audience..$^{54}$

Economic grievances were central for many minority women deputies. Rakhimova raised the issue of the high unemployment among women in Tajikistan. She opposed Prime Minister Nikolai Ivanovich Ryzhkov's initiative of shift work as a means of raising productivity, claiming that in Central Asia, where light industry predominated and mainly employed women, one needed to get women out of night shifts. Rakhimova suggested that establishing new factories in new

\footnotetext{
${ }^{50}$ Svetlana Gomzikova, "Sazhi Umalatova: 'Narod ne khochet byt' tol'ko elektoratom," February 15, 2012, https://svpressa.ru/society/article/52688/.

${ }^{51}$ CPD I, 2: 227.

${ }^{52}$ CPD IV, 1: 529.

${ }^{53}$ Matvienko made a prominent career in contemporary Russia, becoming the first female speaker of the upper chamber of the Russian parliament. Although she continued to voice support for women's equality, she tried to keep it within the scope of official conservatism. Artem Krechetnikov, "Valentina Matvienko kak vtoraia Ekaterina II?," BBC News, September 21, 2011, https://www.bbc.com/russian/russia/2011/09/110921_russia_history_women; Vadim Pal'ko, "Matvienko Predlozhila 'Povyshat' Rol' Zhenshchin v Zhizni', No Ne Sozdavat' Matriarkhat," Snob, accessed November 30, 2019, https://snob.ru/news/170244/.

${ }^{54}$ CPD II, 1: 444; CPD II, 3: 400-2.
} 
spheres of light industry would be a better way to create new jobs. She also urged to accompany the creation of new jobs by infrastructure (daycare, residential, and healthcare) for protecting childhood and motherhood. ${ }^{55}$ Pavlina Mikhailovna Chursina, a weaver from Kazakhstan, nominated by the CSW, raised the same issue by claiming that light industry could not be further intensified, pointing to the detrimental effect of night shifts on women's health (including psychological) which could not be compensated by additional payments. She added that pregnant women needed special conditions at workplace. Chursina concluded that women in light industry had little time to take care of children and that this lack of care contributed to high crime rates. ${ }^{56}$

Nataliia Vasil'evna Lemesheva, an agricultural manager from Belarus, nominated by the CSW, disproved of the poor living conditions of women in agricultural labor and noted that it was difficult for them to have and bring up children. Foregrounding the wellbeing of the rural population and the equality between rural and urban areas, Lemesheva called for more public spending on the social sphere, schools and daycare in particular, and criticized the nonimplementation of the existing programs. She also called for the inclusion of agricultural deputies into the decision-making on the matter. Lemesheva defended collective farms, which could not realize their potential, and lamented the lack of prestige of agricultural labor among the youth. ${ }^{57}$ Elena Ivanovna Podolianina, an agricultural manager from Ukraine, nominated by the Union Council of Collective Farms, also cautioned against destroying collective farms, pointing to their social importance and potential. Discussing their main problems, Podolianina mentioned the high equipment prices and the low agricultural prices. Her solutions were state-centered, as she proposed creating a Ministry of Agriculture (which was created later in 1990), but at the same time called for the autonomy of collective farms. Although she claimed to represent agricultural workers, she opposed the idea of an agrarian party, claiming that rallies and strikes could not provide bread. ${ }^{58}$

Rakhimova also looked for solutions in the Soviet state, maintaining that the budget needed a special section for protecting childhood and motherhood. She cited the high infant mortality in the whole of the USSR but stressed that it was even higher in Central Asia and called for a state program for decreasing it. Rakhimova also recommended more state support for the women with many children, pointing to malnutrition due to the miniscule income per family member in Central Asia. ${ }^{59}$ Bazarova suggested introducing special employment guarantees for women with

\footnotetext{
${ }^{55}$ CPD II, 2: 34.

${ }^{56}$ CPD II, 2: 63.

${ }^{57}$ CPD, II, 2: 291-4.

${ }^{58}$ CPD III, 1: 101-3.

${ }^{59}$ CPD II, 2: 36.
} 
children. ${ }^{60}$ Anna Matveena Kamarovskaia, an economist and an agricultural manager, elected in Moldova, connected motherhood to the political situation, claiming that women wanted peace, order, and certainty for their children's future. ${ }^{61}$

Zaina Beishekeeva, a herder from Kirghizia, nominated by the CPSU, brought attention to the working conditions of livestock herders, especially in sheep breeding. Herders had to work for most of the year in the harsh mountainous climate and were removed from families and cultural life. She also criticized the lack of mechanization. All this, according to Beishekeeva, discouraged young people from such work. Like the agriculturalist deputies, Beishekeeva called for more state support, including salary coefficients and lower retirement age. She also cited the high equipment prices and the low raw material prices and claimed that the situation was applicable to the sheep breeders across the whole country. At the same time, Beishekeeva added a national element to her critique, suggesting that as major wool producer, Kirghizia would benefit from processing it on site. $^{62}$

The women who represented other spheres of economy voiced comparable concerns. Ekaterina Vasil'evna Krivoruchko, an industrial worker from Kazakhstan, nominated by the CSW, elaborated on the issues related to the cement industry, including its environmental impact, and called for union-sponsored solutions. ${ }^{63}$ Irina Iakovlevna Erkhovets, an employee at a computer factory in Belarus, nominated by the CPSU, called for special rights for the computer industry. She noted that the existing factories could not move to self-funding. ${ }^{64}$ Bernara Rakhimovna Karieva, an Uzbek ballet dancer, ${ }^{65}$ nominated by the Union of Theater Employees of the USSR, called for more government spending on culture, citing inter alia the poor living conditions of the theater employees. She also noted the discrepancies in per capita public spending on culture across the union, pointing that it was especially low in Central Asia. ${ }^{66}$

Other women deputies spoke about regional and local issues, which were also expected to be resolved with state support. Podolianina, for instance, noted that lack of access to natural gas among the people in the Vinnytsa Region due to the lack of pipes, despite the fact that gas was transited through the region to Europe.${ }^{67}$ Gaer combined economic, cultural, and environmental grievances of the indigenous population when discussing the situation in the Russian Far East. She

\footnotetext{
${ }^{60}$ CPD II, 2: 50.

${ }^{61}$ CPD III, 3: 42.

${ }^{62}$ CPD I, 3: 207-8.

${ }^{63}$ CPD II, 1: 461-3.

${ }^{64}$ CPD II, 1: 583-4.

65 “Smenilsia Direktor Tashkentskogo Teatra Opery i Baleta Im. Navoi," Fergana.Ru, October 2, 2002, http://www.fergananews.com//article.php?id=909.

${ }^{66}$ CPD II, 2: 96-97.

${ }^{67}$ CPD III, 1: 102.
} 
criticized the intervention of union bodies supervising the extracting industries and the exportoriented economy, calling the Far East a resource appendage of the country. The indigenous Udeges especially suffered from the union forest industry. As she won the elections in a nonexclusively indigenous district in the Far East, she also spoke about general payment coefficients in the region and also proposed a special payment to those returning from the military. ${ }^{68}$

Tamara Musoevna Akramova, a doctor, elected in Tajikistan, also discussed the situation in the Soviet military, pointing to the high mortality. She called for legislation protecting soldiers and suggested a professional army in the future. If the safety of soldiers could not be guaranteed, then, according to Akramova, they should be kept in their own republics. Akramova discussed the matters from a gendered angle, pointing to the women ministers of defense in other countries and claiming that as an authority the deputies were responsible before the mothers of the deceased. ${ }^{69}$

Zoia Nikolaevna Tkacheva, a pediatrician, elected in Belarus, denounced the little concern of the government for the areas affected by the Chernobyl disaster of April 26, 1986. "To date, we, the inhabitants of these areas, have been robbed of clean land, water, air, forests and meadows, without which one cannot live, but can only exist." Vieweing the issue as affecting the whole Belarus nation, Tkacheva cited the health complaints received by local medics and urged scientists to cooperate with them. She then called for medical and other assistance, for gradual resettlement from the affected areas, for indemnity payments by the state, and for creating a permanent agency in the USSR Supreme Soviet. ${ }^{70}$ Alla Aleksandrovna Zgerskaia (Iaroshinskaia), a journalist, elected from the Ukrainian SSR, suggested a state-wide program for the liquidation of the Chernobyl disaster, calling it a tragedy of the whole country. ${ }^{71}$

Muiassar Vaisovna Abdalova, an agricultural worker, elected in Uzbekistan, expressed the grievances of the people in the Khorezm Region who had to endure the consequences of the shrinking of the Aral Sea as a result of the Soviet irrigation projects. Whereas Pruskine blamed the centralized decision-making for this and other environmental disasters, for regional politicians the solution still lay in the aid from the center. Abdalova argued that the official decisions were not supported by material resources and that more money was needed. ${ }^{72}$ Rimadzhan Matnazarovna Khudaibergenova, a party functionary, elected in Uzbekistan, criticized Gorbachev for his lack of attention to the environment, claiming that nothing had been done to save the people of the Aral Sea area and calling the center to implement its decisions. ${ }^{73}$ Bazarova suggested extending the

\footnotetext{
${ }^{68}$ CPD I, 3: 85-91.

${ }^{69} \mathrm{CPD}, \mathrm{IV}, 2: 353$.

${ }^{70}$ CPD I, 2: 313-7.

${ }^{71}$ CPD II, 2: 576-7.

${ }^{72}$ CPD I, 3: 58; CPD II, 1: 457-8.

${ }^{73}$ CPD IV, 1: 234.
} 
special measures to additional areas which were also affected by the Aral Sea crisis. ${ }^{74}$ Beishekeeva called for protecting Lake Issyk-Kul from uncontrolled irrigation and unregulated construction on its banks and claimed that an all-union coordinating body was needed. ${ }^{75}$ Soniiabibi Khushvakhtovna Mukhabatova, an agricultural worker, elected in Tajikistan also called for careful use of natural resources and for a quicker resettlement from the area of the Rogun Dam, which had been constructed since $1976 .{ }^{76}$

\section{Conclusion}

The speeches and statements of minority women deputies highlighted their perspectives on the multifaceted crisis of the Soviet Union. Although on many occasions their critique was not different from that of male deputies, some of the women represented especially marginalized groups, like the indigenous peoples of the Far East and mountain herders of Kirghizia, and for the first time gained the opportunity to express their grievances in a public debate. Furthermore, intersectionality amplified their critiques, as women deputies expressed their concerns from multiple marginalized perspectives. Minority women deputies predominantly articulated grievances, formulated in terms of nationality. This may be explained by the predominance of nationalism in the discourse of the Perestroika and by the leadership of some women in the respective national movements. The representatives of the Baltic republics were especially vocal in their opposition to oppression, understood in ethno-national terms.

The articulation of non-national grievances demonstrated that Soviet women indeed faced a number of interconnected hardships, related to gender, region, locality, and occupation. Some of the issues, like those related to occupation and environment, were part of the broader public discussions. At the same time, the debates at the CPD demonstrated the limits of the official Perestroika discussion. The discussion of economy-related gender grievances fell into the field of acceptable topics of the pre-Perestroika era and hence was not new to the many CPSU members at the congresses, while the previously tabooed gender issues had not yet traversed from the discussions of the "informals" (neformaly) to the reformed government bodies. ${ }^{77}$

Even though their grievances had often been refracted through national categories and also originated in the centralized mismanagement, most of the women deputies viewed the Soviet Union as the main source of possible solutions. Indeed, some women, most of them from the Baltic republics, considered sovereignty (or elements thereof) of the nationally-defined units the most

\footnotetext{
${ }^{74}$ CPD II, 2: 51.

${ }^{75}$ CPD I, 3: 208.

${ }^{76}$ CPD IV, 2: 113.

77 Buckley, "Glasnost and the Woman Question."
} 
viable solution to a whole set of problems, such as economic inequality, the crisis of native languages, and interethnic violence. At the same time, national sovereignty was not necessarily understood as independence, while many women explicitly supported the preservation of the interconnected Soviet space and strengthening of the Soviet state.

Later careers of the deputies, mentioned in the article, demonstrated two trends. Those who continued their engagement in politics were usually those who supported the nationalist angle on the USSR's problems and came from the educated strata. At the same time, the trajectories of individual careers were very different even for the women who expressed similar positions at the CPD. Prunskienè was the first Prime Minister of Lithuania after it declared sovereignty, becoming the country's first female leader. She then continued her political career in the 1990s and 2000s as a member of parliament and as a minister. Prunskienė headed the nationalist conservative yet proRussian Lithuanian People's Party, which in the early 2010s started direct cooperation with Russia's ruling party United Russia. Lari, by contrast, was member not of the Moldovan but of the Romanian parliament, supporting the reunification of the larger Romanian state. Both Prunskiene and Lari led women's political organizations, which meant that the gender aspect of politics remained pivotal for both of them. ${ }^{78}$

Other women who expressed nationalist views at the CPD demonstrated their affinity for social democracy in their later careers. Lauristin, who continued her political career in the 1990s2010s as a member of the Estonian Parliament and the European Parliament and was also a minister, supported the social democratic agenda on both national and European Union levels. In 2012 she was one of the signatories of a public appeal opposing the ruling elites in Estonia and defending democratic procedures. ${ }^{79}$ Khallik, who did not pursue a political career, also expressed social democratic views signing an open letter which foregrounded inequality in Estonia and called for a more socially-oriented economy, in $2001 .^{80}$

Most women who expressed pro-Soviet views at the CPD or occupied prominent positions in the CPSU without joining popular fronts did not continue their political careers in the newly independent states. Kafarova, who supported Azerbaijan's independence and was the first female

\footnotetext{
78 "Kazimira Danute Prunskiene’"; "Putin's Party Fellow Prunskiene Is Unable to Find Political Support in Lithuania," The Lithuania Tribune [Web Archive Copy], October 9, 2011, https://web.archive.org/web/20140413162623/http://www.lithuaniatribune.com/8466/putins-party-fellowprunskiene-is-unable-to-find-political-support-in-lithuania-20118466/; "Ushla iz zhizni poetessa Leonida Lari." 79 “Khartiia 12: Estonskaia Demokratiia Razvalivaetsia Na Glazakh: Vlast' Prodaetsia, vo Imia Polucheniia Vlasti Lgut," Delfi, November 14, 2012, https://rus.delfi.ee/daily/estonia/hartiya-12-estonskaya-demokratiyarazvalivaetsya-na-glazah-vlast-prodaetsya-vo-imya-polucheniya-vlasti-lgut?id=65260400; "Estonian MEP to Resign and Join Tartu City Council,” ERR, October 24, 2017, https://news.err.ee/638283/estonian-mep-to-resign-and-jointartu-city-council.

80 “Sotsiaalteadlaste avalik pöördumine,” Postimees, April 22, 2001, https://arvamus.postimees.ee/1863213/kirjad.
} 
leader of the country, resigned in 1992, supposedly over a conflict with nationalist politicians. ${ }^{81}$ Rakhimova also discontinued her political career but continued her activities in support of women's rights, participating, for example, in teaching courses for women leaders in Tajikistan. ${ }^{82}$ Karieva was not involved in politics, but served as an advisor to the President of Uzbekistan on theater matters. ${ }^{83}$ Indeed, most of the proponents of non-nationalist solutions of Soviet problems also had labor backgrounds, which might have contributed to their non-participation in politics.

Some of the minority women deputies of the CPD continued their political careers in Russia, since most of their constituencies remained part of the reformed federation. Some were critical of the government and official policies. Gaer, who had a brief career in the Russian parliament in the 1990s, continued her public engagement as a prominent speaker for indigenous rights. ${ }^{84}$ Starovoitova, whose engagement in politics started with the Nagorno-Karabakh conflict, also attempted to mitigate the situation Chechnya. She was a deputy of the Russian parliament and planned to participate in presidential elections but was not registered a candidate. In 1998 she was assassinated, with the motives most likely being political but remaining unclear. ${ }^{85}$ Zgerskaia, who was a member of the Inter-Regional Group, continued her carrier in Russia and not in Ukraine. The nuclear nonproliferation matters remained central for her and she had served in advisory bodies of the Russian government. ${ }^{86}$ Umalatova, who participated in the parliamentary elections but did not succeed, became quite prominent in the conservative "opposition" in contemporary Russia. She supported Vladimir Vladimirovich Putin personally but was critical of corruption in the official establishment. ${ }^{87}$

\section{Literature}

ZN.ua. "Bosikom Po Bitomu Steklu," March 20, 2009. https://zn.ua/SOCIETY/bosikom_po_bitomu_steklu-1.html.

Brown, Archie. Seven Years That Changed the World: Perestroika in Perspective. Oxford: Oxford University Press, 2007.

\footnotetext{
${ }^{81}$ Thomas Goltz, Azerbaijan Diary: A Rogue Reporter's Adventures in an Oil-Rich, War-Torn, Post-Soviet Republic (Armonk, NY: M.E. Sharpe, 1998), 134-35.

${ }^{82}$ Mukhaie Kaiumova, "Bikhodzhal Rakhimova: 'Zhenshchiny dolzhny realizovat' svoi liderskii potentsial,"” SugdNEWS, accessed November 30, 2019, http://sugdnews.com/2018/11/30/bihodzhal-rahimova-v-nyneshnihuslovijah-kazhdaja-zhenshhina-mozhet-vybirat-kem-ej-byt/.

83 "Smenilsia Direktor Tashkentskogo Teatra Opery i Baleta Im. Navoi."

84 “Skonchalas' Evdokiia Aleksandrovna Gaer," Tsentr sodeistviia korennym malochislennym narodam Severa, October 4, 2019, http://www.csipn.ru/glavnaya/novosti-regionov/4728-skonchalas-evdokiya-aleksandrovnagaer\#.XeJ_2JNKgWo.

${ }_{85}$ Artem Krechetnikov, “Za chto ubili Galinu Starovoitovu?,” BBC News, November 20, 2018, https://www.bbc.com/russian/features-46280588.

86 “Bosikom Po Bitomu Steklu," ZN.ua, March 20, 2009, https://zn.ua/SOCIETY/bosikom_po_bitomu_steklu1.html.

${ }^{87}$ Gomzikova, "SvobodnaiaPressa."
} 
Buckley, Mary. "Glasnost and the Woman Question." In Women and Society in Russia and the Soviet Union, edited by Linda Edmondson, 202-26. Cambridge: Cambridge University Press, 1992.

Chetvertyi S"ezd narodnykh deputatov SSSR. Stenograficheskii Otchet, 17-27 Dekabria 1990 g. Vol. 2. Moscow: Izdanie verkhovnogo soveta SSSR, 1991.

Chetvertyi S"ezd Narodnykh Deputatov SSSR, 17-27 Dekabria 1990 g.: Stenograficheskii Otchet. Vol. 1. Moscow: Izdanie verkhovnogo soveta SSSR, 1991.

Chetvertyi S"ezd Narodnykh Deputatov SSSR, 17-27 Dekabria 1990 g.: Stenograficheskii Otchet. Vol. 3. Moscow: Izdanie verkhovnogo soveta SSSR, 1991.

Denisova, Liubov. Rural Women in the Soviet Union and Post-Soviet Russia. Edited by Irina Mukhina. London: Routledge, 2010.

ERR. "Estonian MEP to Resign and Join Tartu City Council," October 24, 2017. https://news.err.ee/638283/estonian-mep-to-resign-and-join-tartu-city-council.

Gaidar, Yegor. Collapse of an Empire: Lessons for Modern Russia. Washington, DC: Brookings Institution Press, 2010.

Gerasimov, Ilya, Sergey Glebov, Aleksandr Kaplunovski, Marina Mogilner, and Aleksandr Semyonov. "The Centrality of Periphery." Ab Imperio, no. 1 (2012): 19-28.

Gerasimov, Ilya, Sergey Glebov, Jan Kusber, Marina Mogilner, and Alexander Semyonov. "New Imperial History and the Challenges of Empire." In Empire Speaks out: Languages of Rationalization and Self-Description in the Russian Empire, edited by Ilya Gerasimov, Jan Kusber, and Alexander Semyonov, 3-32. Leiden: Brill, 2009.

Giuliano, Elise. Constructing Grievance: Ethnic Nationalism in Russia's Republics. Ithaca, NY: Cornell University Press, 2011.

Glebov, Oleg, and John Crowfoot, eds. The Soviet Empire: Its Nations Speak out: The First Congress of People's Deputies, Moscow, 25 May to 10 June 1989 (with an Introduction by Ernest Gellner). Chur: Harwood Academic Publishers, 1989.

Goldman, Wendy Z. Women at the Gates: Gender and Industry in Stalin's Russia. Cambridge: Cambridge University Press, 2002.

Goldstein, Steve. "Nationalism Divides Estonia, and a Family." The Philadelphia Inquirer, February 15, 1988, A04.

Goltz, Thomas. Azerbaijan Diary: A Rogue Reporter's Adventures in an Oil-Rich, War-Torn, Post-Soviet Republic. Armonk, NY: M.E. Sharpe, 1998.

Gomzikova, Svetlana. "Sazhi Umalatova: 'Narod ne khochet byt' tol'ko elektoratom,"” February 15, 2012. https://svpressa.ru/society/article/52688/.

Hewett, Ed A. "Perestroyka and the Congress of People's Deputies." Soviet Economy 5, no. 1 (1989): 47-69.

Ihalainen, Pasi, Cornelia Ilie, and Kari Palonen. "Parliament as a Conceptual Nexus." In Parliaments and Parliamentarism: A Comparative History of a European Concept, edited by Pasi Ihalainen, Cornelia Ilie, and Kari Palonen, 1-16. New York: Berghahn Books, 2016.

Kaiumova, Mukhaie. "Bikhodzhal Rakhimova: 'Zhenshchiny dolzhny realizovat' svoi liderskii potentsial." SugdNEWS. Accessed November 30, 2019.

http://sugdnews.com/2018/11/30/bihodzhal-rahimova-v-nyneshnih-uslovijah-kazhdajazhenshhina-mozhet-vybirat-kem-ej-byt/.

Government of the Republic of Lithuania [Web Archive Copy]. "Kazimira Danutė Prunskiene,," October 14, 2006.

https://web.archive.org/web/20061014172146/http://www.lrv.lt/main_en.php?cat=16\&gr $=3 \& \mathrm{sub}=9 \& \mathrm{~d}=2001$.

Delfi. "Khartiia 12: Estonskaia Demokratiia Razvalivaetsia Na Glazakh: Vlast' Prodaetsia, vo Imia Polucheniia Vlasti Lgut,” November 14, 2012. 
https://rus.delfi.ee/daily/estonia/hartiya-12-estonskaya-demokratiya-razvalivaetsya-naglazah-vlast-prodaetsya-vo-imya-polucheniya-vlasti-lgut?id=65260400.

Kotkin, Stephen. Armageddon Averted: The Soviet Collapse, 1970-2000. Updated edition. Oxford: Oxford University Press, 2008.

Krechetnikov, Artem. "Valentina Matvienko kak vtoraia Ekaterina II?" BBC News, September 21, 2011. https://www.bbc.com/russian/russia/2011/09/110921_russia_history_women. . "Za chto ubili Galinu Starovoitovu?" BBC News, November $\overline{20}, 201 \overline{8}$. https://www.bbc.com/russian/features-46280588.

Lentini, Peter. "A Note on Women in the CPSU Central Committee." Europe-Asia Studies 45, no. 4 (1990): 729-36.

Nechemias, Carol. "Politics in Post-Soviet Russia: Where Are the Women?" Demokratizatsiya 8, no. 2 (2000): 199-199.

Pal'ko, Vadim. 'Matvienko Predlozhila 'Povyshat' Rol' Zhenshchin v Zhizni', No Ne Sozdavat' Matriarkhat." Snob. Accessed November 30, 2019. https://snob.ru/news/170244/.

Pervyi S"ezd narodnykh deputatov SSSR. Stenograficheskii Otchet, 25 Maia-9 Iiunia $1989 \mathrm{~g}$. Vol. 1. Moscow: Izdanie verkhovnogo soveta SSSR, 1989.

. Stenograficheskii Otchet, 25 Maia-9 Iiunia 1989 g. Vol. 2. Moscow: Izdanie verkhovnogo soveta SSSR, 1989.

- Stenograficheskii Otchet, 25 Maia-9 Iiunia 1989 g. Vol. 3. Moscow: Izdanie verkhovnogo soveta SSSR, 1989.

_. Stenograficheskii Otchet, 25 Maia-9 Iiunia 1989 g. Vol. 4. Moscow: Izdanie verkhovnogo soveta SSSR, 1989.

The Lithuania Tribune [Web Archive Copy]. "Putin's Party Fellow Prunskiene Is Unable to Find Political Support in Lithuania," October 9, 2011. https://web.archive.org/web/20140413162623/http://www.lithuaniatribune.com/8466/puti ns-party-fellow-prunskiene-is-unable-to-find-political-support-in-lithuania-20118466/.

Reeves, Madelein. Border Work: Spatial Lives of the State in Rural Central Asia. Ithaca, NY: Cornell University Press, 2014.

Regan, Patrick M., and Daniel Norton. "Greed, Grievance, and Mobilization in Civil Wars." Journal of Conflict Resolution 49, no. 3 (2005): 319-36.

Semyonov, Alexander. “'The Real and Live Ethnographic Map of Russia': The Russian Empire in the Mirror of the State Duma." In Empire Speaks out: Languages of Rationalization and Self-Description in the Russian Empire, edited by Ilya Gerasimov, Jan Kusber, and Alexander Semyonov, 191-228. Leiden: Brill, 2009.

Tsentr sodeistviia korennym malochislennym narodam Severa. "Skonchalas' Evdokiia Aleksandrovna Gaer," October 4, 2019. http://www.csipn.ru/glavnaya/novostiregionov/4728-skonchalas-evdokiya-aleksandrovna-gaer\#.XeJ_2JNKgWo.

Fergana.Ru. "Smenilsia Direktor Tashkentskogo Teatra Opery i Baleta Im. Navoi," October 2, 2002. http://www.fergananews.com//article.php?id=909.

Postimees. "Sotsiaalteadlaste avalik pöördumine," April 22, 2001. https://arvamus.postimees.ee/1863213/kirjad.

Stefano, Carolina de. "An Old Soviet Response and a Revolutionary Context: Dealing with the National Question in the Committees of the USSR Congress of People's Deputies (19891991)." Journal of Eurasian Studies 11, no. 1 (2020): 53-61.

Suny, Ronald Grigor. The Revenge of the Past: Nationalism, Revolution, and the Collapse of the Soviet Union. Stanford, CA: Stanford University Press, 1993.

Publika. "Ushla iz zhizni poetessa Leonida Lari," December 11, 2011. https://ru.publika.md/ushla-iz-zhizni-poyetessa-leonida-lari_360631.html.

Valentine, Gill. "Theorizing and Researching Intersectionality: A Challenge for Feminist Geography." The Professional Geographer 59, no. 1 (2007): 10-21. 
Vignoles, Vivian L., Seth J. Schwartz, and Koen Luyckx. "Introduction: Toward an Integrative View of Identity." In Handbook of Identity Theory and Research, edited by Seth J.

Schwartz, Koen Luyckx, and Vivian L. Vignoles, 1-27. New York: Springer, 2011.

Vneocherednoi Piatyi S"ezd narodnykh deputatov SSSR. Biulleten' No. 6, 5 Sentiabria 1991 g. Moscow: Otdel opublikovaniia aktov Verkhovnogo Soveta SSSR, 1991.

Vneocherednoi Piatyi S"ezd Narodnykh Deputatov SSSR: Biulleten' No. 1, 2 Sentiabria 1991 g. Moscow: Otdel opublikovaniia aktov Verkhovnogo Soveta SSSR, 1991.

Vneocherednoi Piatyi S"ezd Narodnykh Deputatov SSSR: Biulleten'No. 2, 2 Sentiabria 1991 g. Moscow: Otdel opublikovaniia aktov Verkhovnogo Soveta SSSR, 1991.

Vneocherednoi Piatyi S"ezd Narodnykh Deputatov SSSR: Biulleten'No. 3, 3 Sentiabria 1991 g. Moscow: Otdel opublikovaniia aktov Verkhovnogo Soveta SSSR, 1991.

Vneocherednoi Piatyi S"ezd Narodnykh Deputatov SSSR: Biulleten'No. 4, 3 Sentiabria 1991 g. Moscow: Otdel opublikovaniia aktov Verkhovnogo Soveta SSSR, 1991.

Vneocherednoi Piatyi S"ezd Narodnykh Deputatov SSSR: Biulleten'No. 5, 4 Sentiabria 1991 g. Moscow: Otdel opublikovaniia aktov Verkhovnogo Soveta SSSR, 1991.

Vneocherednoi Tretii S"ezd narodnykh deputatov SSSR. Stenograficheskii Otchet, 12-15 Marta $1990 \mathrm{~g}$. Vol. 2. Moscow: Izdanie verkhovnogo soveta SSSR, 1990.

Vneocherednoi Tretii S"ezd Narodnykh Deputatov SSSR, 12-15 Marta 1990 g.: Stenograficheskii Otchet. Vol. 1. Moscow: Izdanie verkhovnogo soveta SSSR, 1990.

Vneocherednoi Tretii S"ezd Narodnykh Deputatov SSSR, 12-15 Marta 1990 g.: Stenograficheskii Otchet. Vol. 3. Moscow: Izdanie verkhovnogo soveta SSSR, 1990.

"Vsesoiuznaia Perepis' Naseleniia 1989 Goda: Natsional'nyi Sostav Naseleniia Po Respublikam SSSR.” Accessed September 29, 2019. http://www.demoscope.ru/weekly/ssp/sng_nac_89.php.

Vtoroi S"ezd narodnykh deputatov SSSR. Stenograficheskii Otchet, 12-24 Dekabria $1989 \mathrm{~g}$. Vol. 2. Moscow: Izdanie verkhovnogo soveta SSSR, 1989. . Stenograficheskii Otchet, 12-24 Dekabria 1989 g. Vol. 3. Moscow: Izdanie verkhovnogo soveta SSSR, 1989.

Vtoroi S"ezd Narodnykh Deputatov SSSR, 12-24 Dekabria 1989 g.: Stenograficheskii Otchet. Vol. 1. Moscow: Izdanie verkhovnogo soveta SSSR, 1989. 